IRA-International Journal of Management \& Social Sciences

ISSN 2455-2267; Vol.07, Issue 01 (2017)

Pg. no. 33-38

Institute of Research Advances

https://research-advances.org/index.php/RAJMSS

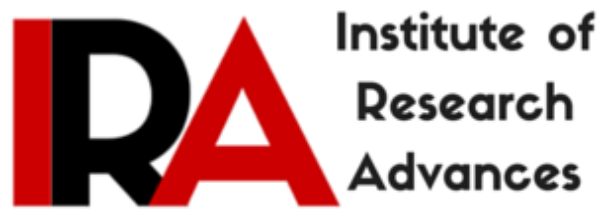

\title{
A Study about increased use of Social Networking Sites
}

\author{
Dr. Paras Jain \\ Director, Silicobyte Katni Degree College, Dikshabhumi Campus, \\ Katni (M.P) Pin 483501, India.
}

Type of Review: Peer Reviewed.

DOI: http://dx.doi.org/10.21013/jmss.v7.n1.p4

\section{How to cite this paper:}

Jain, P. (2017). A Study about increased use of Social Networking Sites. IRA-International Journal of Management \& Social Sciences (ISSN 2455-2267), 7(1), 33-38.

doi:http://dx.doi.org/10.21013/jmss.v7.n1.p4

(C) Institute of Research Advances

(cc) EY-NC

This work is licensed under a Creative Commons Attribution-Non Commercial 4.0 International License subject to proper citation to the publication source of the work.

Disclaimer: The scholarly papers as reviewed and published by the Institute of Research Advances (IRA) are the views and opinions of their respective authors and are not the views or opinions of the IRA. The IRA disclaims of any harm or loss caused due to the published content to any party. 


\section{ABSTRACT}

Present era is the era of internet; communication is fast, easy, accessible and quick. A lot of social networking sites are connecting people. After introducing android smart phones, social network has become powerful medium of expression of views. Persons of all age group like to connect through these sites and post their views. Present study is focused on finding of awareness about social networking sites. These sites have turned world into a global village.

Keywords: Social Networking Site , Communication , Marketing

\section{Introduction:}

Social network users make their own profile within a framework and add a list of users with whom they may make connections. These sites are used to send photo, audio, video and text matter. Communication through these sites is possible in all over the world. These sites are charge free to use. Whatever a person is thinking it is possible to communicate at same time to all connectors. Not only individuals but also organizations take advantage of social network. A person may connect with friends, relatives, colleagues and all other whom he wants to connect. Similarly organizations are connected with their clients and helpful to make popular their product, concept etc. These sites are becoming popular day by day as no. of users are increasing so business organizations are seeing these sites as advertisement sites.

According to the latest report released by com Score, a marketing research company, out of total internet users in India, 84 percent users visit the social networking sites. This makes India the world's seventh largest social network sites visitor. United States is the largest and number one social network website visitor country among all the countries. China is on number two following US with total of 97.1 million users and is followed by Germany who had 37.9 million visitors with the growth rate of 47 percent. It had 25.7 million unique visitors. There are various types of networking sites; most popular among them are Facebook, Twitter, Linkedin, Orkut etc. Except sharing of views, experience, academic matter people use these sites for chatting also.

\section{Face book}

Face book is the most popular social networking site in the world, based on the number of active user accounts. It is number one in India as visited by 226.5 million visitors. It is for Profit Corporation, social media and networking service. Face book classifies users from the ages of 13 to 18 as minors and therefore sets their profiles to share content with friends only.

\section{Bharatstudent.com}

Bharat student is a student networking channel connecting young Indians worldwide. It is best web sites for students here the students can get easily solutions related to their subjects, many web sites which are in the on line but they are not worth it at all. It has 3 percent growth in its unique visitors as compared over the last year.

\section{Twitter.com}

On twitter, one can discover what is happening right now anywhere in the world. Twitter with 3.3 million unique visitors is social networking website visited by Indians. Twitter had the highest growth rate increasing 239 percentages from the last year. 8 percent of total internet users use twitter in India while it is used by 20 percent internet users in Indonesia and Brazil. This site promoted micro-blogging continues to grow and become more active. This is the go-to site for all users whether it's celebrities or 
organizations. The simple interface has appealed to a lot of people and the website shows no signs of decline.

\section{LinkedIn.com}

Indians are now exchanging information, ideas and opportunities through LinkedIn and therefore, it led to rise in the users of LinkedIn in India. In India it is accessed by 3.3 million unique visitors. This website caters to the business and professional community and is one of the most active in India. A lot of people are registering and using the website. LinkedIn provides the opportunity for users to build their business profile with important factors such as experience, education, and business networks.

\section{Instagram}

Instagram was bought by Facebook in 2012 for around $\$ 1$ billion and doubled its base of monthly active users in India during the period between September 2015 and September 2014.

\section{Google Plus}

Google Plus has been slowly increasing and upgrading its features in the last few years. The positive thing about this social networking site is it allows you to customize and organize people and interests into circles.

\section{Hike Messenger}

Hike Messenger is a cross-platform instant messaging service for smart phones that uses the internet for communication. In addition to text messaging, users can send each other graphical stickers, emoticons, images, videos, audios, files, voice messages, contacts and user location.

\section{Skype}

Skype allows users to communicate over the Internet by voice using a microphone, by video using a webcam, and by instant messaging. Skype-to-Skype calls to other users are free of charge, while calls to landline telephones and mobile phones (over traditional telephone networks) are charged via a debitbased user account system called Skype Credit.

\section{Face book Messenger}

Face book messenger (sometimes abbreviated as Messenger) is an instant messaging service and software application which provides text and voice communication.

\section{WhatsApp}

WhatsApp crossed 80 million monthly active users in India, which is also its largest country by the number of monthly active users which is $10 \%$ of its total user base. 
Table-1: Status of Social Networking Sites in India

\begin{tabular}{|l|l|}
\hline Social Networking Site & $\begin{array}{l}\text { Share of } \\
\text { Population \% }\end{array}$ \\
\hline Face book & 13 \\
\hline Whats app & 12 \\
\hline Face book Messenger & 11 \\
\hline Google Plus & 10 \\
\hline Skype & 10 \\
\hline Twitter & 8 \\
\hline Hike Messenger & 8 \\
\hline LinkedIn & 7 \\
\hline Instagram & 7 \\
\hline We Chat & 6 \\
\hline
\end{tabular}

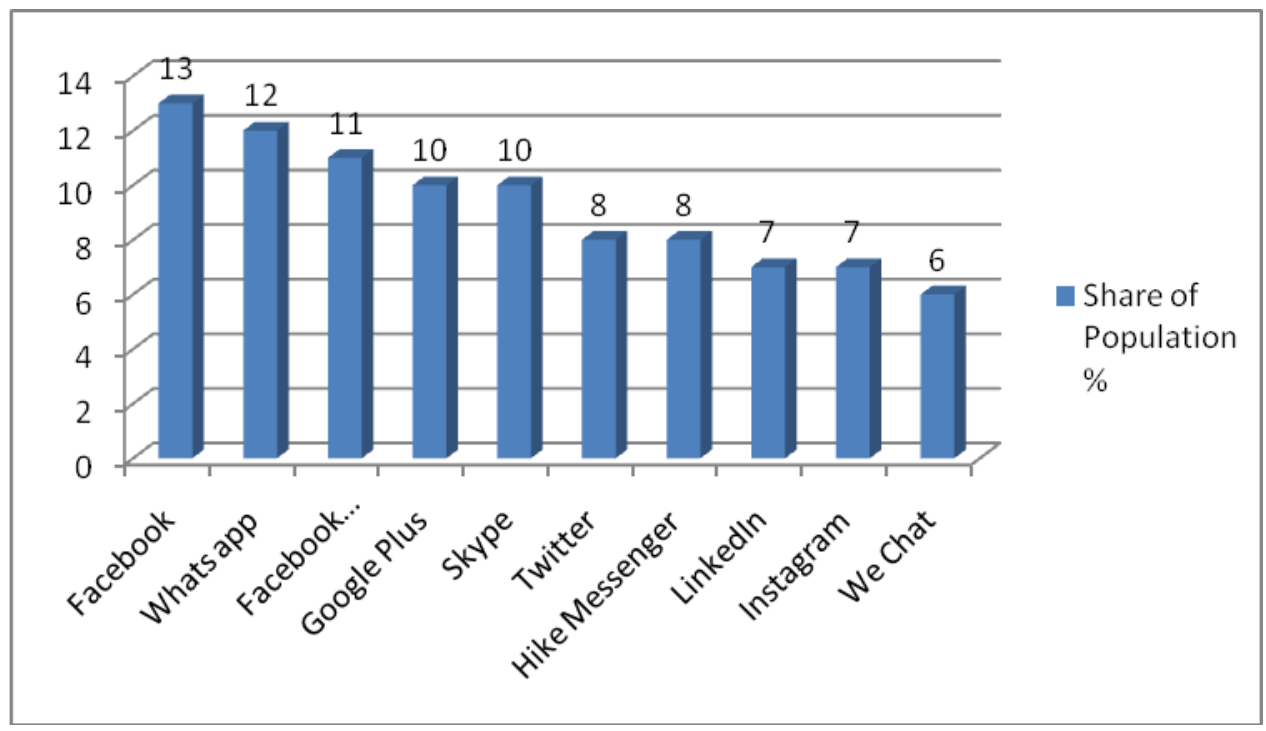

Chart-1: Status of Social Networking Sites in India

\section{Objective of Study:}

To know awareness about social networking sites among adolescents

\section{Sample:}

The sample consists of 200 adolescents of age 14-19 years out of which 100 were boys and 100 girls. 


\section{Tool:}

A self prepared questionnaire was used to find status about awareness. Question paper consists of questions like name and no. of social networking site used, spent time, positive and negative aspects etc.

Table-2: Status of Social Network Sites User (Locality and gender wise)

\begin{tabular}{|l|l|l|}
\hline \multirow{2}{*}{$\begin{array}{l}\text { User } \\
\text { Category }\end{array}$} & \multicolumn{2}{|l|}{$\begin{array}{l}\text { Social } \\
\text { Site User \% }\end{array}$} \\
\cline { 2 - 3 } & Urban & Rural \\
\hline Boys & 82 & 54 \\
\hline Girls & 74 & 48 \\
\hline
\end{tabular}

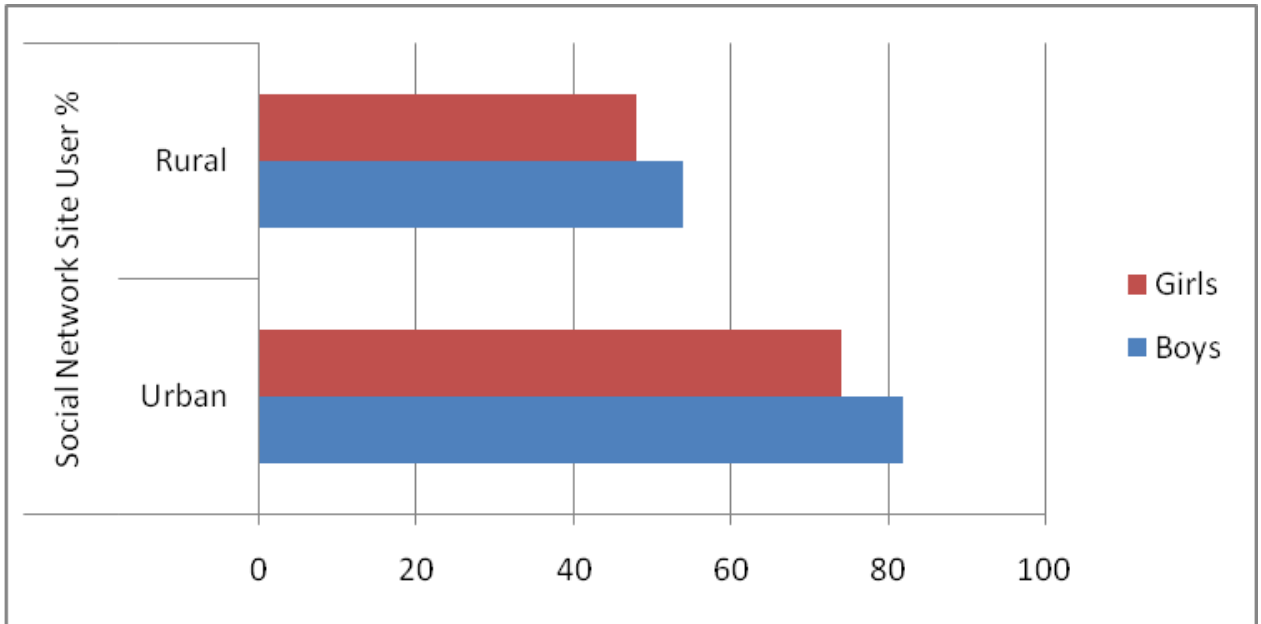

Chart-2: Status of Social Network Sites User (Locality and gender wise)

Table-3: Status of Social Network Sites User (Age group and gender wise)

\begin{tabular}{|l|l|l|}
\hline \multirow{2}{*}{$\begin{array}{l}\text { Age } \\
\text { Group }\end{array}$} & \multicolumn{2}{|l|}{$\begin{array}{l}\text { Social } \\
\text { Site User \% }\end{array}$} \\
\cline { 2 - 3 } & Boys & Girls \\
\hline $14-16$ & 77 & 67 \\
\hline $17-19$ & 82 & 76 \\
\hline $20-22$ & 87 & 79 \\
\hline
\end{tabular}




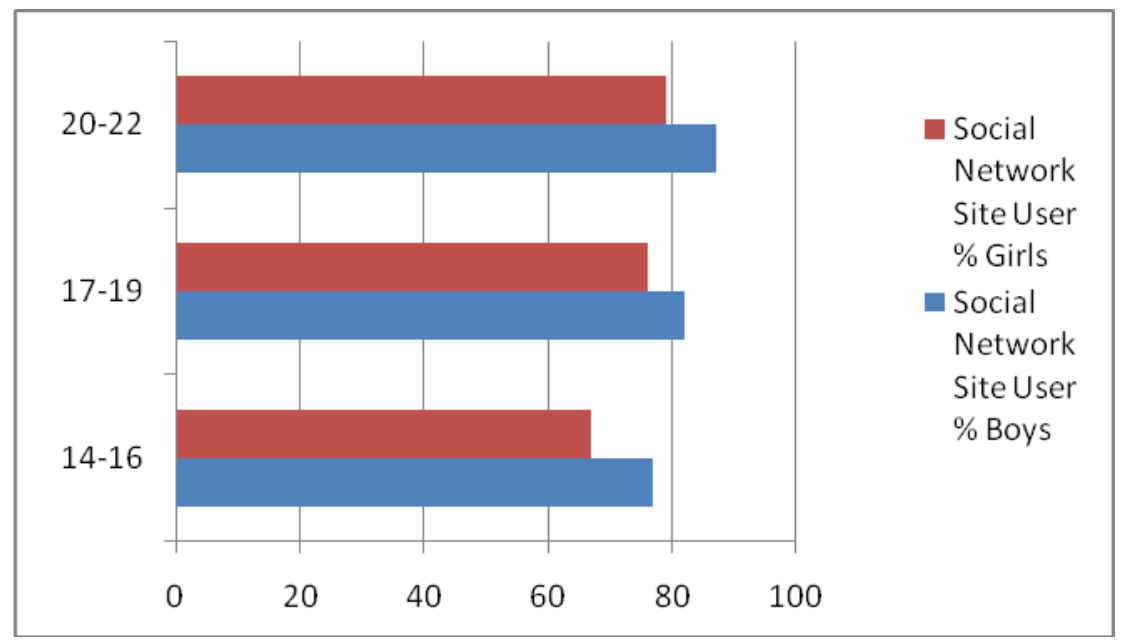

\section{Chart-3: Status of Social Network Sites User (Age group and gender wise)}

Social networking sites are used by majority of adolescents. Result shows that $82 \%$ urban boys and 54\% rural boys are social network site users. Among girls user \% is low rather than boys i.e., 74\% urban and $48 \%$ rural. Age group wise data shows that with increase in age user $\%$ increased among boys and girls both.

\section{Conclusion:}

Social Networking sites in India generate a huge amount of traffic compared with other countries, but it's not just population density that equates for this traffic. India is without a doubt becoming one of the most technologically active countries in the world, producing talented graduates in the fields of IT, Engineering, Programming, Data Analysis, among others. Many developers, start-ups and tech companies have started expanding into this country due to their technological advancements. This early-development of technology is the major reason India is known for being most active on social media. The number of users from India is growing exponentially as the internet becomes more accessible in both urban and rural areas.

\section{References:}

1. http://growingsocialmedia.com/social-networking-sites-in-india.

2. http://smallbiztrends.com

3. http://en.m.wikiedia.org 